\title{
Performance of Nellore calves in tropical pasture consuming different types of concentrated supplements
}

\author{
[Desempenho de bezerros Nelore em pastagem tropical consumindo diferentes \\ tipos de suplementos concentrados] \\ M. Vedovatto ${ }^{1}$, M.B. Meirelles ${ }^{1}$, M.C. D'Oliveira ${ }^{1}$, J.M.S. Diogo ${ }^{2}$, M.G. Morais ${ }^{1}$, \\ C.L. Abreu ${ }^{3}$, I.M. Cortada Neto ${ }^{1}$, G.L. Franco ${ }^{1 *}$ \\ ${ }^{1}$ Universidade Federal de Mato Grosso do Sul - Campo Grande, MS \\ ${ }^{2}$ Universidade de Brasília - Brasília, DF \\ ${ }^{3}$ Universidade Estadual de Mato Grosso do Sul - Aquidauana, MS
}

\begin{abstract}
The use of different types of concentrated supplements on the performance of Nellore calves grazing Urochloa brizantha cv. Marandu in the dry season was evaluated. The experiment was conducted on 24 ha divided into 12 paddocks. Seventy-two calves with initial body weight (BW) $176 \pm 14 \mathrm{~kg}$ for 140 days of experiment were used. Evaluated treatments included: Mineral, Salt+urea (mineral with $30 \%$ urea), Protein (supplementation with $45 \%$ crude protein (CP) and $46 \%$ total digestible nutrients (TDN)); and Protein+energy (with 28\% CP and 73\% TDN). The Mineral, Salt+urea, and Protein were offered ad libitum, and the Protein+energy 5g/kg BW. Protein+energy showed the highest $(\mathrm{P}<0.05)$ intake $(3.66 \mathrm{~g} / \mathrm{kg}$ BW) followed by the Protein (1.61), Salt+urea (0.36), and Mineral (0.32). The two latter supplements were not significantly different $(\mathrm{P}>0.05)$. The highest $(\mathrm{P}<0.05)$ average daily gain $(\mathrm{ADG}, \mathrm{kg} / \mathrm{day})$ was observed in the Protein+energy (0.074). Average daily gains for the Protein and Salt+urea $(0.014$ and 0.024 , respectively) were not significantly different $(\mathrm{P}>0.05)$, but were significantly higher $(\mathrm{P}<0.05)$ than the Mineral (-0.085). Therefore, during the dry season, to prevent the loss of bovine weight the supplements must supply in addition to minerals, also energy, non-protein nitrogen (NNP), and true protein.
\end{abstract}

Keywords: energy, multiple mixes, protein, Urochloa brizantha cv. marandu

\section{RESUMO}

Foi avaliada a utilização de tipos de suplementos concentrados sobre o desempenho de bezerros Nelore em pasto de Urochloa brizantha $\mathrm{cv}$. Marandu na época seca. O experimento foi conduzido em 24ha divididos em 12 piquetes. Foram utilizados 72 bezerros com peso corporal (PC) inicial de $176 \pm 14 \mathrm{~kg}$ por 140 dias de experimento. Os tratamentos foram: mineral, mineral+ureia (mineral com $30 \%$ de ureia); proteinado (suplemento com $45 \%$ de $P B$ e $46 \%$ de nutrientes digestiveis totais (NDT)); suplemento energético (suplemento com $28 \%$ de PB e $73 \%$ de NDT). Mineral, mineral+ureia e proteinado foram fornecidos ad libitum, e o suplemento proteico-energético $5 \mathrm{~g} / \mathrm{kg}$ de PC. O consumo do suplemento $(\mathrm{g} / \mathrm{kg}$ de $P C)$ foi maior $(P<0,05)$ para o suplemento proteico-energético $(3,66)$, seguido por proteinado $(1,61)$, mineral+ureia $(0,36)$ e mineral $(0,32)$. Esses dois últimos não diferiram entre si $(P>0,05)$. O maior $(P<0,05)$ GMD ( $\mathrm{kg} / \mathrm{dia})$ foi para o suplemento proteico-energético $(0,074)$, seguido por proteinado e mineral+ureia $(0,014$ e -0,024, respectivamente), que não diferiram entre si $(P>0,05)$. Todos estes foram superiores $(P<0,05)$ ao mineral $(-0,085)$. Assim, durante a época seca, para prevenir a perda de peso de bovinos, os suplementos devem fornecer, além de minerais, energia, nitrogênio não proteico (NNP) $e$ proteína verdadeira.

Palavras-chave: energético, mistura múltipla, proteinado, Urochloa brizantha cv. Marandu

Recebido em 13 de fevereiro de 2017

Aceito em 25 de maio de 2018

* Autor para correspondência (corresponding author)

E-mail: gumercindo.franco@ufms.br 


\section{INTRODUCTION}

Quantitative and qualitative changes occur in tropical pastures during the drought and rainy seasons and in the transition period (Fernandes et al., 2016). These tropical pastures accumulate $77-90 \%$ of the total dry matter production (DM) during the rainy season between the months of October and February, comprising high stocking rates in this period. Drastic reductions in carrying capacity occur in the dry season reducing the production of DM and hence, $\mathrm{CP}$ and TDN (Euclides et al., 2009).

Deferring use of pastures during the flooding season until the dry season is an alternative to overcome the limitations of mass forage supply, but this has low nutritional value, and may present CP percentages below 4\% (Moretti et al., 2013). Levels of CP lower them $8 \%$ may affect the multiplication of ruminal microorganisms, and, as a consequence, reduce the rate of passage and the intake of the forage (Detmann et al., 2014). However, pasture deferral coupled with feed supplements can meet the nutritional requirements of animals by offering an increased supply of nutrients and increased fiber forage degradation efficiency (Euclides et al., 2009).

The type of supplement, composition, ingredients used, quantity consumed, quality and quantity of forage offered as well as interactions among these components are variables that affect cattle performance (Dixon e Stockdale, 1999; Fernandes et al., 2016). Thus, this study evaluated the use of concentrated supplements on the performance of Nellore calves grazing in marandu grass pastures during the dry season.

\section{MATERIAL AND METHODS}

The experiment was conducted in the Água Limpa Farm (FAL) from the Universidade de Brasília (UNB), Distrito Federal, located at $15^{\circ} 55^{\prime} 12.55^{\prime \prime} \mathrm{S}$ and $47^{\circ} 55^{\prime} 12.55^{\prime \prime} \mathrm{W}$ at an altitude of 1,000 meters. Average annual rainfall is $1,500 \mathrm{~mm}$. The experiment was conducted over 140 days during the dry season (corresponding to five periods of 28 days each) between the months of June and October of 2008. A total of 72 weaned, non-castrated, seven to eight month old Nellore calves weighing $176 \pm 14 \mathrm{~kg}$ were used.
The experimental protocols were approved by the Ethics Committee on the use of animals from Universidade Federal de Mato Grosso do Sul under case no. 210/2009.

The experimental area consisted of 12 paddocks (4 blocks of 3 paddocks) with 2 ha each covered with marandugrass pasture, Urochloa brizantha (Hochst. Ex A. Rich) R. D. Webster, cv. Marandu [syn. Brachiaria brizantha (Hochst.Ex A. Rich) Stapf]. The pasture was not in use for three months before the beginning of the study to ensure a good supply of forage mass for the animals. All paddocks had drinkers with automatic replenishment and covered troughs with manual replenishment. Six animals were housed in each paddock and animals were rotated weekly within each block. The rainfall and temperature data during the experimental period were obtained from the FAL/UNB weather station (Figure 1).

The experimental treatments were defined according to the type of supplement supplied (Table 1): Mineral (mineral supplement), Salt+urea (mineral supplement with $30 \%$ urea), Protein (supplementation with $45 \% \mathrm{CP}$ and $46 \%$ TDN); and Protein+energy (supplementation with $28 \% \mathrm{CP}$ and $73 \% \mathrm{TDN}$ ). The Mineral, Salt+urea, and Protein supplements were offered ad libitum, and the Protein+energy was offered at $5 \mathrm{~g} / \mathrm{kg}$ of BW (DM based).

Animals were weighed every 28 days, during the morning after fasting from solids and liquids for 16 hours. The ADG of animals was calculated as the difference between the initial and final weight in each experimental period, divided by the number of days.

Forage mass was determined every 28 days using a metal square of $0.5 \mathrm{~m}^{2}$ randomly thrown into eight spots inside a paddock, and the cut was conducted at $5 \mathrm{~cm}$ from the ground. The samples were weighed in the field, homogenized, and two sub-samples removed. One of these was used to determine DM and estimated forage mass; the other was used to determine the morphological constitution of the plant through the manual separation of the green blade, stem and sheath, and dead material (Table 2). 


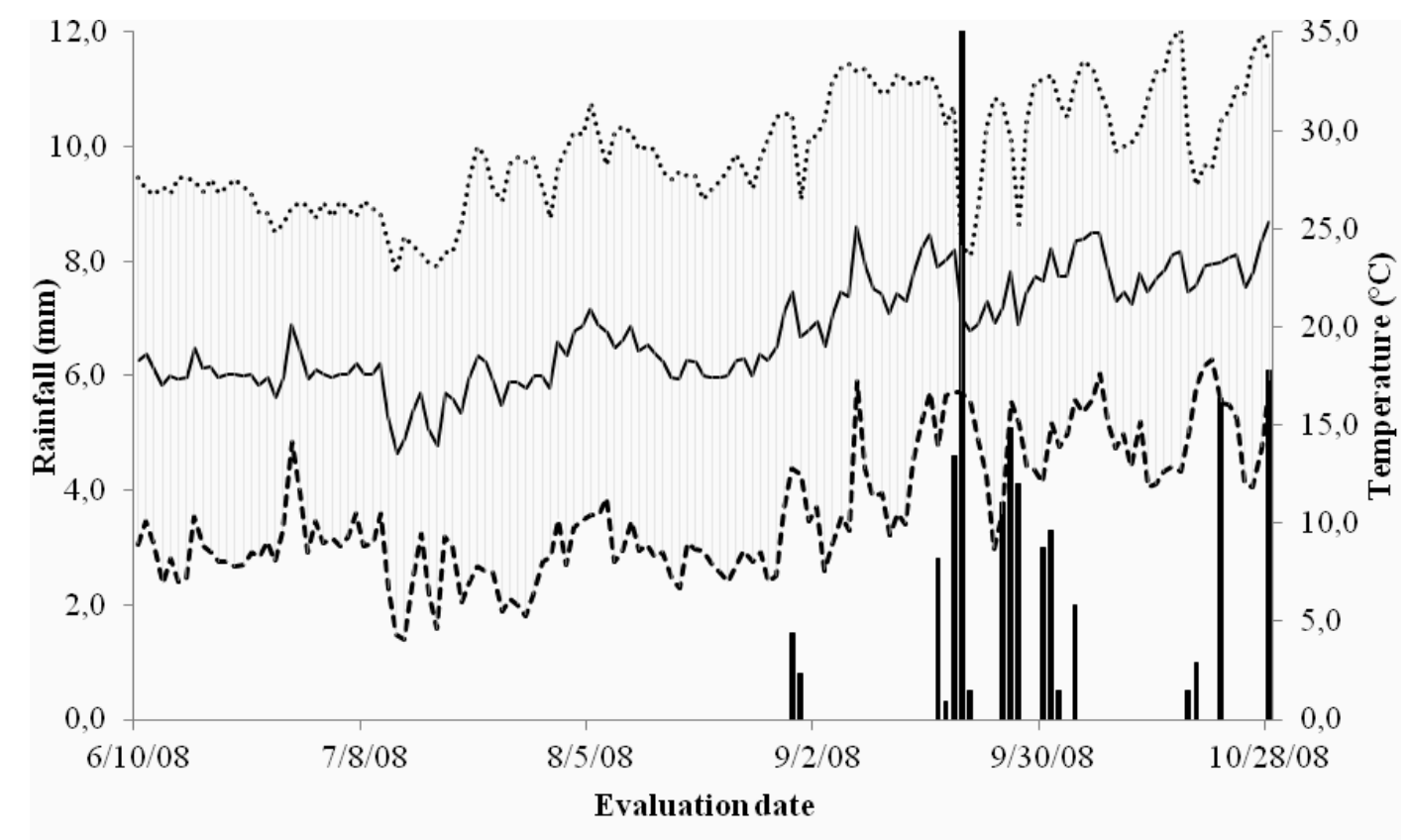

Rainfall (mm)

Av erage temp $\left({ }^{\circ} \mathrm{C}\right)$

Maximumtemp $\left({ }^{\circ} \mathrm{C}\right)$

Minimumtemp $\left({ }^{\circ} \mathrm{C}\right)$

Figure 1. Average rainfall and temperature during the experiment (Jun-Oct of 2008) at the Água Limpa Farm, Distrito Federal, Brazil.

The stocking rate (SR) was calculated from the sum of BW of animals in each paddock divided by the weight of one animal unit $(\mathrm{AU}=450 \mathrm{~kg})$ and the paddock area. The total DM (TDM) in the pasture and green blades were calculated as follows: Supply $=(a$ /SR $) /$ days where " $a "$ corresponds to TDM or green blades and "days" to the number of days in each period.

Table 1. Participation and chemical composition of ingredients in the supplements offered to calves grazing on marandu grass during the dry season

\begin{tabular}{|c|c|c|c|c|}
\hline \multirow{2}{*}{ Item } & \multicolumn{4}{|c|}{ Supplements } \\
\hline & Mineral & Salt+urea & Protein & Protein+energy \\
\hline \multicolumn{5}{|c|}{ Composition of supplements (\%) } \\
\hline Corn & - & - & 45.00 & 65.00 \\
\hline Soybean meal & - & - & 16.00 & 17.00 \\
\hline Urea & - & 30.00 & 12.00 & 5.00 \\
\hline $\mathrm{NaCl}$ & - & - & 12.00 & 7.00 \\
\hline Mineral mixture $^{1}$ & 100 & 70.00 & 15.00 & 6.00 \\
\hline \multicolumn{5}{|l|}{ Chemical composition $(\%)^{2}$} \\
\hline Dry matter & 97.15 & 87.91 & 88.57 & 88.51 \\
\hline Crude protein & - & 84.00 & 45.16 & 28.25 \\
\hline Neutral detergente fiber & - & - & 9.22 & 11.51 \\
\hline Ether extract & - & - & 2.85 & 3.20 \\
\hline Ashes & - & - & 25.42 & 13.46 \\
\hline Non-fibrous carbohydrates & - & - & 39.07 & 52.63 \\
\hline Total digestible nutrients & - & - & 45.95 & 73.50 \\
\hline
\end{tabular}

${ }^{\mathrm{I}}$ Mineral mixture used in the Mineral and Salt+urea supplements: g/kg (Ca 160, P 80, S 12, Mg 5, Na 128) mg/kg (Co 68, Cu 1240, Fe 1600, I 64, Mn 1120, Se 12.2, Zn 3280, F 800). Protein and Protein+energy: g/kg (Ca 150, P 42, S 48, Mg 36, Na 70) mg/kg (Co 50, Cu 600, Fe 1500, I 40, Mn 1400, Se 10, Zn 2400, F 420). ${ }^{2}$ Non-fibrous carbohydrates $(\mathrm{NFC}=100-[(\%$ Total $\mathrm{CP}-\% \mathrm{CP}$ urea $+\%$ urea $)+\% \mathrm{FDN}+\% \mathrm{EE}+\%$ ashes $] ;$ HALL, 2000); Total digestible nutrients (TDN= [91.0246 - 0.571580 x FDN]; Cappelle et al., 2001). 
Forage samples and supplements from each paddock were analyzed according to AOAC (Official..., 1990): DM using method 930.15; CP using method 976.05; ether extract (EE) using method 920.39; and ash using method 942.05. The filter bags technique (TNT-tissue-nontissue) was used to determine the neutral detergent fiber (NDF) content. Each bag measured $5 \mathrm{x} 5 \mathrm{~cm}$ with 100 micrometers porosity, to which $0.5 \mathrm{~g}$ of feed sample was added. Analyses used a neutral detergent solution (Van Soest et al., 1991) in the Tecnal equipment
(TE-149; Tecnal, Piracicaba, SP, Brazil). Estimation of the pasture's non-fibrous carbohydrates (NFC) was calculated using the equation $N F C=100-C P+$ ashes $+N D F+E E$ according to Sniffen et al. (1992). The NFC content of supplements due to the presence of urea was calculated by the equation $N F C=100$ $[(\%$ total CP -\%CPurea $+\%$ urea $)+\% N D F+$ $\% E E+\% a s h e s]$ according to Hall (2000). The TDN content was calculated by the equation TDN $=91.0246-0.571580 \times \mathrm{NDF}$ according to Cappelle et al. (2001) (Table 2).

Table 2. Forage mass, components, and chemical composition of marandu grass

\begin{tabular}{lcccccc}
\hline \multirow{2}{*}{\multicolumn{1}{c}{ Variables }} & \multicolumn{5}{c}{ Evaluation period (day/month of 2008) } \\
\cline { 2 - 7 } & $06 / 10$ & $07 / 08$ & $08 / 05$ & $09 / 02$ & $09 / 30$ & $10 / 28$ \\
\hline Forage mass and components & 5034.6 & 4761.5 & 4625.2 & 4573.4 & 4236.1 & 3898.3 \\
Forage mass (kg/ha of DM) & 20.0 & 12.4 & 3.3 & 1.5 & 1.1 & 4.2 \\
Green leaf (\%) & 55.2 & 46.0 & 51.4 & 50.9 & 51.8 & 37.9 \\
Stem (\%) & 24.8 & 41.6 & 45.3 & 47.6 & 47.1 & 57.9 \\
Dead material (\%) & & & & & & \\
Chemical composition (\%) & 92.97 & 94.73 & 94.21 & 93.63 & 94.21 & 93.93 \\
DM & 2.90 & 1.76 & 1.72 & 1.35 & 1.50 & 1.79 \\
CP & 72.57 & 74.64 & 75.68 & 77.87 & 81.06 & 81.18 \\
NDF & 1.49 & 1.14 & 1.16 & 0.93 & 0.80 & 1.03 \\
EE & 17.17 & 16.84 & 16.05 & 14.81 & 11.86 & 11.18 \\
NFC & 49.54 & 48.36 & 47.77 & 46.52 & 43.69 & 44.62 \\
TDN & 17.08 & 27.48 & 27.77 & 34.46 & 29.13 & 24.92 \\
TDN/CP & &
\end{tabular}

${ }^{1} \mathrm{DM}$, dry matter; CP, crude protein, NDF, neutral detergent fiber; EE, ether extract; NFC, non-fibrous carbohydrates $(\mathrm{NFC}=100-\mathrm{CP}+$ ashes $+\mathrm{NDF}+\mathrm{EE} ;$ Sniffen et al., 1992), TDN, total digestible nutrients $(\mathrm{TDN}=91.0246-$ 0.571580 x NDF; Cappelle et al., 2001).

The design of randomized complete blocks with four treatments was used. Each group (with 6 animals) was considered one experimental unit and was evaluated in three repetitions (12 group). For the statistical analysis of all variables, the PROC MIXED (SAS Inst. Inc., Cary, NC) was used. The Satterthwaite approximation was used to determine the degrees of freedom of the denominator for fixed effects. The statistical models contained as fixed effect treatment and as random variables calf (group) and group (treatment). All results are reported as LSmeans and are separated by STD. The PDIFF function was used to separate the data when significance was detected by the F-test. Significance was set when $\mathrm{P} \leq 0.05$.

\section{RESULTS AND DISCUSSION}

The highest intake of concentrated supplement (Table 3) was observed $(\mathrm{P}<0.05)$ in the Protein+energy group, followed by the Protein, Salt+urea, and Mineral groups, respectively. The same intake pattern was observed for $\mathrm{CP}$ and TDN in the supplements. The animals treated with the Protein+energy and Protein supplement showed higher $(\mathrm{P}<0.05)$ weight gain per ha (WG/ha) and final stocking rate (AU/ha) than those treated with the Protein supplement, however, this Protein supplement did not differ (P> 0.05) from the Salt+urea, and this did not differ $(\mathrm{P}>0.05)$ from the Mineral treatment. The highest $\mathrm{ADG}(\mathrm{P}<0.05)$ was observed in the animals treated with the Protein+energy, followed by the Protein and Salt+urea supplement, which were similar $(\mathrm{P}>0.05)$. The Mineral group showed the lowest ADG $(\mathrm{P}<0.05)$.

The highest supplement intake was observed in the Protein+energy group and may be due to this supplement containing the smallest amounts of $\mathrm{NaCl}$ and urea (Table 1). These are the main and most efficient ingredients used as limiting components in supplements for ruminants (Paulino et al., 2005). 
Table 3. Supplement intake, stocking rate and performance of calves grazing marandu grass during the dry season

\begin{tabular}{|c|c|c|c|c|c|c|}
\hline \multirow{2}{*}{ Variables $^{2}$} & \multicolumn{4}{|c|}{ Treatments $^{1}$} & \multirow{2}{*}{ STD } & \multirow{2}{*}{$\begin{array}{c}\mathrm{p} \\
\text { Value }\end{array}$} \\
\hline & Mineral & Salt+urea & Protein & Protein+energy & & \\
\hline \multicolumn{7}{|l|}{ Intake (supplement) } \\
\hline DM (g/anim/day) & $54.20^{\mathrm{c}}$ & $65.06^{\mathrm{c}}$ & $290.49^{b}$ & $671.45^{\mathrm{a}}$ & 48.347 & 0.0001 \\
\hline $\mathrm{DM}(\mathrm{g} / \mathrm{kg} / \mathrm{BW})$ & $0.32^{\mathrm{c}}$ & $0.36^{\mathrm{c}}$ & $1.61^{\mathrm{b}}$ & $3.66^{\mathrm{a}}$ & 0.266 & 0.0001 \\
\hline $\mathrm{CP}(\mathrm{g} / \mathrm{kg} / \mathrm{BW})$ & $0.00^{\mathrm{d}}$ & $0.31^{\mathrm{c}}$ & $0.73^{\mathrm{b}}$ & $1.04^{\mathrm{a}}$ & 0.127 & 0.0001 \\
\hline TDN (g/kg/BW) & $0.00^{\mathrm{c}}$ & $0.00^{\mathrm{c}}$ & $0.74^{\mathrm{b}}$ & $2.69^{\mathrm{a}}$ & 0.174 & 0.0001 \\
\hline ADG (kg/day) & $-0.085^{\mathrm{c}}$ & $-0.024^{b}$ & $0.014^{\mathrm{b}}$ & $0.074^{\mathrm{a}}$ & 0.522 & 0.0001 \\
\hline WG/ha $(\mathrm{kg})$ & $-35.38^{c}$ & $-10.00^{\mathrm{bc}}$ & $5.60^{\mathrm{ab}}$ & $30.80^{\mathrm{a}}$ & 9.315 & 0.0012 \\
\hline ISR (AU/ha) & $1.18^{\mathrm{a}}$ & $1.17^{\mathrm{a}}$ & $1.18^{\mathrm{a}}$ & $1.18^{\mathrm{a}}$ & 0.015 & 0.9200 \\
\hline FSR (AU/ha) & $1.10^{\mathrm{c}}$ & $1.15^{\mathrm{bc}}$ & $1.19^{\mathrm{ab}}$ & $1.25^{\mathrm{a}}$ & 0.023 & 0.0010 \\
\hline
\end{tabular}

${ }^{\mathrm{I}}$ Mineral, only mineral mixture; Salt+urea, supplementation of mineral with $30 \%$ urea; Protein, supplementation with $45 \% \mathrm{CP}$ and 46\% TDN; Protein+energy, supplementation with $28 \% \mathrm{CP}$ and $73 \%$ TDN. Mineral, Salt+urea, and Protein were offered ad libitun, and Protein+energy was offered at $5 \mathrm{~g} / \mathrm{kg}$ BW (based on DM).

${ }^{2} \mathrm{DM}$, dry matter; $\mathrm{CP}$, crude protein, TDN, total digestible nutrients; ADG: average daily gain; WG/ha: weight gain per hectare; ISR: initial stocking rate; FSR: final stocking rate;

Averages with same letters are not significantly different by the Tukey's test $(\mathrm{P}<0.05)$; STD: average standard deviation.

The Protein+energy group showed the highest ADG and reflected an increased consumption of $\mathrm{CP}$ and TDN. Because this treatment contains minerals, $\mathrm{CP}$ and TDN may also have caused the increase on intake of forage by the animals (Dixon e Stockdale, 1999). The increase on intake by animals fed in low-quality pastures whose diets were enhanced with concentrated supplements results from a positive-associative effect usually attributed to the addition of limiting nutrients, such as nitrogen and sulfur, for microorganisms. The supply of limiting nutrients to ruminal microorganisms leads to high multiplication rates resulting in increased passage rate, intake, and consequently weight gain (Dixon e Stockdale, 1999).

Figure 2 shows alterations in body weight (BW) during the experiment. There were no differences $(\mathrm{P}>0.05)$ between the initial BW and those at 28 and 56 days $(07 / 08$ and 08/05/2008, respectively). The average initial $\mathrm{BW}$ was $176.3 \mathrm{~kg}, 175.2 \mathrm{~kg}, 176.6 \mathrm{~kg}$, and $176.6 \mathrm{~kg}$ in animals consuming the Mineral, Salt+urea, Protein, and Protein+energy respectively. The effects of supplements began to appear at the fourth weighing (09/02/2008) when the Protein+energy and Protein groups showed higher BW $(\mathrm{P}<0.05)$ than the Mineral group; the Salt-urea group did not differ from the other treatments $(\mathrm{P}>0.05)$. The Protein+energy group did not differ from the Protein $(\mathrm{P}>0.05)$ at the fifth weighing (09/30/2008) and they were both higher than the Salt+urea and Mineral $(\mathrm{P}<0.05)$ groups, which presented the lowest weight gains $(\mathrm{P}<0.05)$. The Protein+energy and Protein groups showed the highest $\mathrm{BW}(\mathrm{P}<0.05)$ at the final weighing (10/28/2008). However, the Protein group did not differ from the Salt+urea group $(\mathrm{P}>0.05)$ while the Salt+urea group did not differ from the Mineral group (P>0.05). The final average BWs were $164.47 \mathrm{~kg}, 171.86 \mathrm{~kg}$, $178.44 \mathrm{~kg}$, and $186.92 \mathrm{~kg}$ in animals receiving the Mineral, Salt+urea, Protein, and Protein+energy, respectively.

As the forage quality decreased during the period from $06 / 10 / 2008$ to $09 / 30 / 2008$, dependence on nutrients provided by the supplements increased in order for animals to maintain or gain weight (Figure 2). The Mineral and Salt-urea treatments did not efficiently compensate for the forage nutritional deficiency: animals consuming these supplements showed lower body weight at the end of the experiment. The increased in rainfall in the months of September and October (Figure 1) improved forage quality and resulted in a slight improvement in animal performance at the end of the experiment (10/28/2008).

The Protein+energy provided greater ADG than the other supplements probably by providing greater amounts of TDN and CP. The proportion of non-protein nitrogen (NPN) provided by urea $(\mathrm{NPN}=14 \%)$ in this supplement was approximately $50 \%$ of the total CP content 
(28.25\%). According to Ceconi et al. (2015), increasing urea nitrogen in dietary supplements during the low peak of ammonia production may improve its use by ruminal bacteria. Fernandes et al. (2016) recommended that $\mathrm{CP}$ content in the Protein supplements should be only $33 \%$ and should come from NPN at the beginning of the dry season.

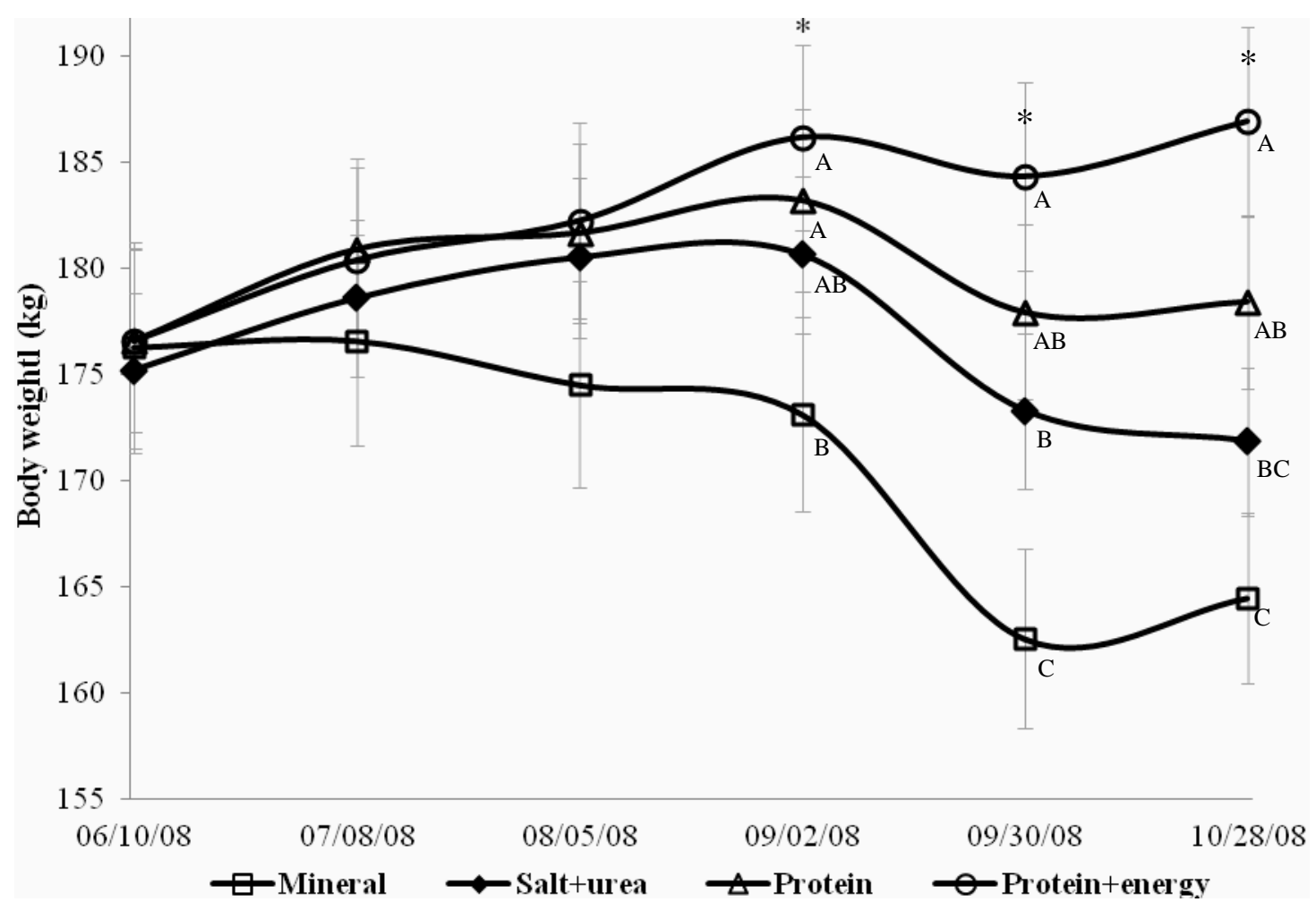

Figure 2. Alterations in $\mathrm{BW}$ of calves grazing on marandu grass and consuming the following supplements: Mineral, only mineral mixture; Salt+urea, supplementation of mineral with $30 \%$ urea; Protein, supplementation with $45 \% \mathrm{CP}$ and $46 \% \mathrm{TDN}$; Protein+energy, supplementation with $28 \% \mathrm{CP}$ and $73 \%$ TDN. Mineral, Salt+urea, and Protein were offered ad libitun, and Protein+energy was offered at $5 \mathrm{~g} / \mathrm{kg} \mathrm{BW}$ (based on DM). *Averages with same dates and letters are not significantly different by the Tukey's test $(\mathrm{P}<0.05)$; Vertical bars represent the average standard deviation.

Most ruminal bacteria (over 90\%) can use ammonia to synthesize nitrogenous compounds; however, a small portion (amylolytic bacteria) needs amino acids derived from protein (Kozloski, 2011). Thus, the balance in the TDN/CP ratio, CP degradation rates, and the supply of minerals are essential for the optimal development of ruminal microorganisms and consequent animal weight gain.

Thus, this study breaks the paradigm that supplementation of Salt+urea in the dry season prevents the loss of weight or increases the dry matter intake of deferred pasture. It shows that the success of the effects of supplementation depends on two factors: the type of supplement and the quality of the pasture offered to the animals. When the pasture quality factor is not considered the use of urea does not prevent weight loss, the Protein can maintain the weight of the animals and Protein+energy supplementation with restricted consumption leads to derisory gains in a long period of drought (4 months). This probably happens because it has no associative effect between the DMI of the supplement and the DMI of the residue of deferred pasture. Thus, probably the forage mass is not able to supply sufficient energy so that the animals can express some extra weight gain. 


\section{CONCLUSION}

The supplementation of mineral mixture or mineral mixture with urea in the diet of calves grazing in tropical pastures during the dry season is not sufficient to meet maintenance requirements. The Protein+energy produced greater weight gain by providing nitrogen in the form of NPN and as true protein than the other supplements studied. Further studies are needed to verify if the differential in weight gain produced by the Protein+energy is maintained in different fattening systems.

\section{REFERENCES}

CAPPELLE, E.R.; VALADARES FILHO, S.C.; SILVA, J.F.C.; CECON, P.R. Estimativa do valor energético a partir de características químicas e bromatológicas dos alimentos. Rev. Bras. Zootec., v.30, p.1837-1856, 2001.

CECONI, I.; RUIZ-MORENO, M.J.; DILORENZO, N. et al. Effect of slow-release urea inclusion in diets containing modified corn distillers grains on total tract digestibility and ruminal fermentation in feedlot cattle. J. Anim. Sci., v.93, p.4058-4069, 2015.

DETMANN, E.; VALENTE, E.E.L.; BATISTA, E.D.; HUHTANEN, P. An evaluation of the performance and efficiency of nitrogen utilization in cattle fed tropical grass pastures with supplementation. Livest. Sci., v.162, p.141$153,2014$.

DIXON, R.M.; STOCKDALE, C.R. Associative effects between forages and grains: consequences for feed utilization. Aust. J. Agric. Res., v.50, p.757-773, 1999.

EUCLIDES, V.P.B.; MACEDO, M.C.M.; VALLE, C.B. et al. Valor nutritivo da forragem e produção animal em pastagens de Brachiaria brizantha. Pesqui. Agropec. Bras., v.44, p.98106, 2009.
FERNANDES, R.M.; ALMEIDA, C.M.; CARVALHO, B.C. et al. Effect of supplementation of beef cattle with different protein levels and degradation rates during transition from the dry to rainy season. Trop. Anim. Health. Prod., v.48, p.95-101, 2016.

HALL, M.B. Calculation of non-structural carbohydrate content of feeds that contain non protein nitrogen. Florida: University of Florida, 2000. p.A25 (Bulletin, 339).

KOZLOSKI, G.V. Metabolismo dos compostos nitrogenados. In: KOZLOSKI, G.V. Bioquímica dos ruminantes. 3.ed. Santa Maria: UFSM, 2011. cap. 1, p.80-86.

MORETTI, M.H.; RESENDE, F.D.; SIQUEIRA, G.R. et al. Performance of Nellore young bulls on Marandu grass pasture with protein supplementation. Rev. Bras. Zootec., v.42, p.438446, 2013.

OFFICIAL methods of analysis. 15.ed. Arlington: AOAC International, 1990. 1117p.

PAULINO, M.F.; MORAES, E.H.B.K.; ZEVOURDAKIS, J.T. et al. Fontes de energia em suplementos múltiplos de auto regulação de consumo na recria de novilhos mestiços em pastagens de Brachiaria decumbens durante o período das águas. Rev. Bras. Zootec., v.34, p.957-962, 2005.

SNIFFEN, C.J.; O'CONNOR, J.D.; VAN SOEST, P.J. et al. A net carbohydrate and protein system for evaluating cattle diets; II. Carbohydrate and protein availability. J. Anim. Sci., v.70, p.3562-3577, 1992.

VAN SOEST, P.J.; ROBERTSON, J.B.; LEWIS, B.A. Methods for dietary fiber, neutral detergent fiber, and non-starch polysaccharides in relation to animal nutrition. J. Dairy. Sci., v.74, p.35833597, 1991. 